\title{
Association between Socio-Economic Factor, Home Sanitation, Sense of Belonging, and Health Behavior, in Patients with Dengue Hemorrhagic Fever in Kediri, East Java
}

\author{
Lindha Sri Kusumawati'), Ambar Mudigdo²), Soemanto3) \\ 1)Faculty of Health Sciences, Kadiri University \\ 2)Faculty of Medicine, Universitas Sebelas Maret \\ 3)Faculty of Social and Political Sciences, Universitas Sebelas Maret
}

\begin{abstract}
Background: Dengue hemorrhagic fever (DHF) is an infectious disease characterized by high fever and red spots on the skin with unclear causal factor. The increasing number of DHF cases for the past few years indicated poor environmental health indicator. The purpose of this study was to determine theassociation between socio-economic factor, home sanitation, sense of belonging, and health behavior, in patients with DHF.

Subjects and Method: This was an analytic observational study with case control design.This study was conducted at Campurejo Health Center, Kediri, East Java.A total sample of 100 patients with DHF were selected for this study. The dependent variable was health behavior. The independent variables were socio-economic factor, home sanitation, and sense of belonging. The data were collected by questionnaire and analyzed by multiple logistic regression.

Results: Education $\geq$ senior high school $(\mathrm{OR}=3.15 ; 95 \% \mathrm{CI}=1.22$ to $8.14 ; \mathrm{p}=0.018)$, family income $\geq$ regional minimum wage $(\mathrm{OR}=9.14 ; 95 \% \mathrm{CI}=3.13$ to $26.70 ; \mathrm{p}=0.001)$, good home sanitation $(\mathrm{OR}=$ $3.10 ; 95 \% \mathrm{CI}=1.12$ to 8.58; $\mathrm{p}=0.029)$, and sense of belonging $(\mathrm{OR}=12.01 ; 95 \% \mathrm{CI}=4.02$ to 35.89 ; $\mathrm{p}=0.001$ ) were associated with healthier behavior.

Conclusion: Education $\geq$ senior high school, family income $\geq$ regional minimum wage, good home sanitation, and sense of belonging are associated with healthier behavior.
\end{abstract}

Keywords: education, family income, home sanitation,sense of belonging, health behavior

Correspondence:

Lindha Sri Kusumawati. Faculty of Health Sciences, Kadiri University. Email:lindha.sri@gmail.com.

\section{BACKGROUND}

Dengue Hemorrhagic Fever (DHF) is an infectious disease characterized by high fever and red spots on the skin with unclear causal factor. DHF is caused by the dengue virus that is transmitted to humans through the bite of the Aedes aegepty mosquito (Ministry of Health RI, 2013). Since 2013, the World Health Organization (WHO) has recorded Indonesia as a country with the highest DHF cases in Southeast Asia. In 2014 until mid-December, there were 71,668 people in 34 provinces in Indonesia suffering from DHF, and 641 of them died (Indonesian Health Profile, 2014).
DHF is not only caused by the dengue virus, but also caused by many vectors of the Aedes Aegypti mosquito. The increasing number of vectors occurs because there are many breeding places. Climate change can extend the period of disease transmission through vector and change the geographical area. It may also spread to areas with low population immunity or low public health infrastructure. Furthermore, the risk factors which affect DHF transmission are environmental factors, urbanization, population mobility, population density, and transportation (Ministry of Health RI, 2011). 
Journal of Health Promotion and Behavior (2016), 1(4): 239-244

https://doi.org/10.26911/thejhpb.2016.01.04.03

DHF prevention has been carried out by the Ministry of Health of the Republic of Indonesia which prioritizes preventive and promotive activities by mobilizing and empowering communities in eradicating mosquito nests PSN activities have been carried out intensively since 1992. In 2002, it was developed into $3 \mathrm{M}$ Plus. "3M plus" activities are draining water reservoirs, closing water reservoirs, burying unused items and using mosquito repellent, utilizing unused items, maintaining larvae-eating fish, and so on. These efforts have not shown significant result. One of the causes of the nonoptimal efforts was there was no change in community behavior in PSN (Director General of P2PL of Health Department RI, 2008).

DHF which occurs repeatedly is caused by direct and indirect factors. According to interviews conducted with surveillance of DHF in Campurejo Community Health Center, According to interviews conducted with surveillance of dengue fever in the Campurejo Community Health Center, the types of houses in Bandar Kidul Village are quite varied, some of them are in accordance and some of them are not in accordance with the requirements of a healthy home. Some families have the behavior of hanging clothes behind the door. This place becomes a mosquito shelter. In addition, they have water reservoirs without any covers. Different attitudes from the community caused by varied educational backgrounds. As a result, people occupation is also varied and the sense of belonging of the awareness of maintaining environmental cleanliness among the community is low.

There are differences in education, occupation, and community behavior in maintaning their home environment. Therefore, the researchers were interested in conducting a study about "Association be- tween socio-economic factor, home sanitation, sense of belonging, and health behavior, in patients with dengue hemorrhagic fever in Kediri".

\section{SUBJECTS AND METHOD}

This study used an analytic observational study with case control design. This study was conducted at Campurejo Community Health Center, Kediri.

The population was communities living in Bandar Villlage, Campurejo Community Health Center area. A total sample of 100 patients with DHF were selected by random sampling. The independent variables were education, income, sense of belonging, and home sanitation. The dependent variable was health behavior of DHF. This study used multiple logistic regression for analyzing the data.

RESULTS
This study has been conducted at Campu-
rejo Community Health Center, Kediri, East
Java. The subjects of the study were 75 peo-
ple. The characteristics of the subjects of
the study are explained in Table 1 .
The result of the analysis showed that
the education variable had positive associa-
tion which statistically significant on health
behavior (p=0.018). The subjects of the stu-
dy that had high education had likelihood
of health behavior 1.069 smaller than the
subjects of the study that had low education
(OR=1.07;95\% CI=1.00 to 4.31 ).
There was a positive association
which statistically significant between inco-
me variable and health behavior (p=
o.002). The subjects of the study that had
high income had likelihood of health
behavior 66.52 smaller than the subjects of
the study that had low income (OR=66.52;
$95 \%$ CI =6.35 to 44.20 ).


There was a positive association which statistically significant between home sanitation and health behavior $(\mathrm{p}=$ o.002). The subjects of the study that had good sanitation home had likelihood of health behavior 8.88 times smaller than the subjects of the study that had poor home sanitation $(\mathrm{OR}=8.88 ; 95 \% \mathrm{CI}=1.31$ to 60.23$)$.
There was a positive association which statistically significant between sense of belonging and health behavior $(\mathrm{p}=0.002)$. The subjects of the study that had sense of belonging had likelihood of health behavior 41.64 smaller than the subjects of the study that had poor sense of belonging $(\mathrm{OR}=41.6-$ $2 ; 95 \% \mathrm{CI}=5.96$ to 29.48$)$.

Table 1. Bivariate analysis on the determinants of healthy behavior in DHF patients

\begin{tabular}{lcccccc}
\hline \multirow{2}{*}{ Independent Variables } & \multicolumn{9}{c}{ Health Behavior } & \multirow{2}{*}{ OR } & \multirow{2}{*}{ p } \\
\cline { 2 - 5 } Education & Poor & \% & Good & \% & & \\
Low (<SHS) & 27 & 64.29 & 15 & 35.71 & \multirow{2}{*}{3.15} & 0.018 \\
High ( $\geq$ SHS) & 12 & 36.36 & 21 & 63.64 & & \\
Income & & & & & & \\
Low (<minimum wage) & 32 & 72.73 & 12 & 27.27 & 9.14 & 0.00 \\
High ( $\geq$ minimum wage) & 7 & 22.58 & 24 & 77.42 & & \\
Home sanitation & 31 & 60.78 & 20 & 39.22 & \multirow{2}{*}{3.1} & 0.029 \\
Tidak Sehat & 8 & 33.33 & 16 & 66.67 & & \\
Sehat & & & & & & \\
Sense of belonging & 29 & 74.36 & 10 & 25.64 & 12.01 & 0.00 \\
$\quad$ No & 10 & 27.78 & 26 & 72.22 & & \\
$\quad$ Yes & & & & &
\end{tabular}

Table 2. The analysis of multiple logistic regression of socio-economic factor, home sanitation, sense of belonging, and health behavior

\begin{tabular}{lcccc}
\hline \multicolumn{1}{c}{ IndependentVariable } & OR & \multicolumn{2}{c}{$\mathbf{9 5 \%}$ CI } & \multirow{2}{*}{ p } \\
\cline { 3 - 4 } & & Lower Limit & Upper Limit & \\
\hline Education( $\geq$ SHS) & 1.07 & 1.01 & 4.30 & 0.018 \\
Income ( $\geq$ minimum wage) & 66.52 & 6.35 & 44.2 & 0.002 \\
Home Sanitation (Healthy) & 8.88 & 1.31 & 60.23 & 0.025 \\
Sense of belonging (Yes) & 41.62 & 5.96 & 29.47 & $<0.001$ \\
N Observation & 150 & & & \\
Likelihood Ratio & 53.19 & & \\
Nagelkerke R & $65.5 \%$ & & \\
\hline
\end{tabular}

\section{DISCUSSION}

The result of the study showed that there were several behavioral reasons from the individuals because there was no public concern. This is in line with the theory of Lawrence W. Green, which analyzed health behavior by pointing out that behavior is one of the functions of the presence or absence of information about health or health facilities (accessibility of information). Socialization is one of the factors that deter- mine the success of a program.

Education is one of the standards for the development of a community system. The better the level of education, the better the behavior of individuals in maintaining the environment health. This is in line with a study conducted by Wahyu (2009), which states that education affects a person in behaving healthy. The lower education level of a person gives a bad impact on the health behavior of the person. Education level is 
Journal of Health Promotion and Behavior (2016), 1(4): 239-244

https://doi.org/10.26911/thejhpb.2016.01.04.03

one of the factors which affect decision making on daily behavior. An individual with high education has the ability to determine priority needs in life, especially in maintaining health. The higher the education level, the higher the awareness in maintaining health for themselves and the environment.

The result showed that income had a significant association with behavior. The result of this study is in accordance with a study conducted by Teguh (2007), which states that income affects a person in behaving healthy. The higher the income, the easier the way to fulfill the basic needs in maintaining physical health.

Someone who has enough or more income will be able to meet primary, secondary and tertiary needs. The better the economic condition, the more optimal the individual effort in supporting healthy behavior at cost, such as the prevention of the spread of DHF mosquitoes.

The result of the study showed that there was a significant association between home sanitation and health behavior of DHF sufferers. This result is in accordance with a study conducted by Sofie (2011), which states that home sanitation affects people in behaving healthy.

The main vector of DHF disease in Indonesia is the Aedes Aegypti mosquito. Aedes Aegypti mosquitoes are urban. They live in urban areas and often live inside and around the house (domestic) and closely related to humans. The breeding places are found inside and outside the house. The prevention efforts on Aedes Aegypti mosquitos population have been conducted by eradicating the nest, which is known as PSN movement with $3 \mathrm{M}$ plus. It was carried out systematically, continuously, and simultaneously, thus creating a clean and healthy environment and not conducive for Aedes Aegypti mosquitoes to live (Judarwanto, 2007 in CHPSC, 2007).
The result of the study showed that there was a significant association between sense of belonging and health behavior of DHF sufferers. This result is in accordance with a study conducted by Nindia (2005), which states that sense of belonging affects people in behaving healthy. The better sense of belonging will create healthy behavior which is needed by someone in maintaining health and environment.

Sense of belonging which aims to always care about health becomes standard of mental development in a society. Individuals and groups who take part in preventing the spread of DHF mosquitoes can help to decreas the incidence of DHF sufferers. Sense of belonging can be realized by being active in the PSN movement, working together to clean the home environment, and reporting to health workers when finding patients with signs of DHF symptoms. Therefore, it can create a conducive healthy environment.

Based on the results of this study, income factor is the most influential factor on the health behavior of patients with DHF. The community is expected to be able to maintain the cleanliness of the house and the environment and make a mutual cooperation groupswhich aim to maintain the cleanliness of the surrounding environment and raisethe awareness of environmental cleanliness which is become a shared responsibility.

\section{REFERENCE}

Director General of P2PL of Health Department RI (2008). Data surveilans epidemiologi tahun 2007 (Data surveillance epidemiology year). Depkes RI: Jakarta.

Green CW (2009). Pengobatan untuk Demam berdarah dengue (Treatment for dengue fever). Yayasan Spiritia. Jakarta 
Ministry of Health RI (2011). Subdirektorat pengendalian arbovirosis-Dit PPBB dan PL (Subdirectorate of control of Arbovirosis-Dit PPBB and PL). Retrieved from https://www.academia.edu/9806038/Subdirektorat_Pengendali an_Arbovirosis-Dit_PPBB-Ditjen_PP_PETUNJUK_TEKNIS_PENGGUNAAN_RAPID_DIAGNOSTIC_TEST _RDT_UNTUK_PENUNJANG_DIA GNOSIS_DINI_DBD

Ministry of Health RI (2013). Pengendalian demam berdarah dengue untuk pengelola program DBD Puskesmas (Dengue fever control for DBD program management Puskesmas). Retrieved from https://pkmgkj-tr.com/downlot.php?file=Buku\%2oSaku\%2OPenge ndalian\%20DBD.pdf

Health Profile of Indonesia (2014). Departemen Kesehatan Republik Indonesia Jakarta (Ministry of Health Republic of Indonesia Jakarta). Retrieved from http://www.depkes.go.id/resources/d ownload/pusdatin/profil-kesehatanindonesia/profil-kesehatan-indonesia-2014.pdf
Sofie P (2011). Pengaruh sanitasi lingkungan rumah tinggal dengan kejadian penyakit demam berdarah dengue di Kecamatan Sumbersari Jember (The effect of environmental sanitation in residential with dengue fever disease in Sumbersari district, Jember). Retrieved from https://repository.unej.ac.id/bitstream/handle/123456789/5 582/Skripsi.pdf?sequence $=1$

Wahyu M (2009). Hubungan antara perilaku kesehatan dengan kejadian demam berdarah di Puskesmas Cepiring Kabupaten Kendal (Relationship between health behavior with dengue fever in Cepiring public health center Kendal district). Retrieved from https://lib.unnes.ac.id/159/

WHO (1997). Dengue haemorrhagic fever: diagnostic, treatment, prevention and control, 2nded. Geneva. Retrieved from https://apps.who.int/iris/handle/10665/41988.

Zamroni (2000). Paradigma pendidikan masa depan (Future education paradigm). Yogyakarta: Bigraf Publishing. 